DOI: https://doi.org/10.34069/AI/2021.44.08.14

How to Cite:

Rebrina, L.N. (2021). Semantic and motivational characteristics of enmity vocabulary: the relevance of structural motivation. Amazonia Investiga, 10(44), 149-159. https://doi.org/10.34069/AI/2021.44.08.14

\title{
Semantic and motivational characteristics of enmity vocabulary: the relevance of structural motivation
}

\section{Семантико-мотивационная характеристика лексики вражды: значимость структурной мотивации}

Received: August 6, 2021

Accepted: September 6, 2021
Written by:

Rebrina L.N. ${ }^{57}$

https://orcid.org/0000-0003-0512-980X

ResearcherID: G-6420-2015,

Scopus Author ID: 56241972800,

SPIN: 3971-1615

\section{Abstract}

The object of the research includes the actual designations of the subject with the semantics of enmity, formed with the active foreign language word-formation components, functioning in Russian-language online media and Internet communication in 2000-2020. The approaches used include system-centric and text-centric, semasiological and onomasiological approaches, motivational, definitional, functional-semantic and contextual analysis. It analyses the syntagmatics, semantics, word's inner form, type of motivation, motivational form and meaning, motivational and classification features, lexical and structural motivators, ways of discursive actualising the motivational relations of the studied words. It is shown that selected lexical units with the component -phobe, -phrenic, saur, -down, -hater, -oid, -oholik, -path, -man, (e)rast belong to the vocabulary of enmity depending on their significative or pragmatic component, implement a negative assessment of intellectual, psychological, moral qualities of the subject. The actual vectors of developing the nominal vocabulary of enmity in the Russian language are determined by integration, intensification, internationalization, intensification. The relevant word-forming tendencies in the studied group of nouns are highlighted - the frequency of word composition, non-usual ways of word formation, nominations by analogy, the increasing role of onyms, the activity of word-forming components

\begin{abstract}
Аннотация
Объектом исследования выступают актуальные обозначения субъекта с семантикой вражды, образуемые с участием активных иноязычных словообразовательных компонентов, функционирующие в русскоязычных онлайн-СМИ и интернет коммуникации 2000-2020 гг. Используются системоцентрический и текстоцентрический, семасиологический и ономасиологический подходы; мотивационный, дефиниционный, функционально-семантический контекстуальный анализ. Анализируются синтагматика, семантика, внутренняя форма слова, тип мотивированности, мотивационные форма и значение, мотивировочные и классификационные признаки, лексические и структурные мотиваторы, способы дискурсивной актуализации мотивационных связей исследуемых слов. Показано, что отобранные лексические единицы с компонентами -фоб, френ, - заврг, -даун, -хейтер, -оид, -(о)голик, пат, -ман, -(е)раст относятся к лексике вражды по сигнификативному или прагматическому компоненту их значения, реализуют негативную оценку интеллектуальных, психологических, моральных качеств субъекта. Определены актуальные векторы развития именной лексики вражды в русском языке интеграция, интенсификация, интернационализация, интенсификация.
\end{abstract}

\footnotetext{
${ }^{57}$ Doctor of Philology, Professor of the Department of German and Roman Philology, Volgograd State University, Russia; Leading research scientist of the Department of Mass Communication Languages, Ural Federal University named after the First President of Russia B. N. Yeltsin, Russia.
} 
with a negative rating. It is demonstrated that motivational relations of lexemes are discursively implemented through the actualization of lexical and structural motivation, the paradigmatic value of lexemes, the subjective modality that the addressee uses, his/her individual motivation of words.

Keywords: internet communication, motivational relation, motivology, nominal derivation, semantics of enmity.

\section{Introduction}

Motivation is a fundamental mechanism of language that didn't get a proper reflection at the moment. Motivation is a global, universal category closely connected with onomasiology, semasiology, syntagmatics, paradigmatics, epidigmatics, linguistic consciousness, a variety of extra- and linguistic factors (Blinova, 2012; Cano, 2020; Dobrovol'skij \& Piirainen, 2018). Its study is an urgent task in the context of an integrated understanding of the socio-historical, socio-cultural, ontological, psychophysiological and gnoseological, pragmatic conditionality of language (Blinova, 2012; Morozkina, Rusinakova \& Ivanova, 2020; Cano, 2020; Gombocz, 2013, pp. 45-56; Olostiak, 2019). Nominative-motivational models determine the functioning of the lexical-semantic systems of language (Galitsyna, 2018). Nominativemotivational relations characterise the reflective structure of language and sign, the relationship between linguistic and mental categories, the conditionality of linguistic facts by nonlinguistic ones, the relationship of actual language facts with antecedents (Khazimullina, 2015; Anscombre, 2019; Balestero, Clempi, \& Da Costa, 2020; Chishman, dos Santos, \& Martins, 2020; Detry,2017; Rebrina, 2020; Ulrich, 2020; Umbreit, 2010). Modern internet communication shows widespread enmity, the aggression of various kinds, which makes for active neological processes in this sphere. The above-mentioned and the social significance of the study subject (modern enmity vocabulary, reflecting current social processes in society) makes the study of semantic and motivational
Выделены

релевантные словообразовательные тенденции в исследуемой группе существительных частотность словосложения, неузуальных способов словообразования, номинации по аналогии, возрастающая роль онимов, активность словообразовательных компонентов с отрицательной оценкой. Демонстрируется, что мотивационные связи лексем дискурсивно реализуются посредством актуализации их лексической или структурной мотивации, парадигматической значимости, эксплицируемой адресантом субъективной модальности, его индивидуальной мотивации слов.

Ключевые слова: именное словообразование, интернет-коммуникация, мотивология, мотивационные отношения, семантика вражды.

characteristics and development trends of the relevant lexical subset of the Russian language a demanded and promising prospect.

The objective of our research is as follows: 1) to determine the composition of the paradigmatic subset of new Russian-language subject designations with enmity semantics, including a foreign-language word-formation component, functioning in online media and Internet communication in 2000-2020; analyze the motivational, semantic, syntagmatic characteristics of these units; 2) to systematize the selected subject designations according to semantic features and structural motivators; 3 ) to reveal the role of structural motivators in forming enmity semantics and motivational meaning of units; 4) to identify and characterize current trends in the development of enmity vocabulary in the Russian language on the example of the studied group of lexical units; 5) to describe the current word-formation trends within the group of new subject designations with the semantics of enmity; 6) to demonstrate relevant ways of discursive disclosure of motivational relations and the word's inner form of the studied neolexemes of enmity. Criteria for the selection of language material include a) the presence of the semantic feature "designation of the subject" in the meaning of the lexeme and the belonging of the word to the semantic field "Enmity" due to the significative or pragmatic component of its meaning; b) the functioning of the lexeme in online media, Internet communication in 2000-2020; c) the presence of 


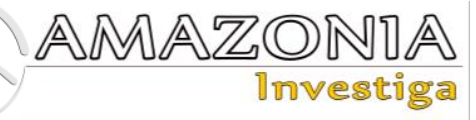

a foreign word-forming component and its activity in developing new subject designations with the semantics of enmity; the significance of structural motivation in forming the semantics of the unit, reflected in the repeated classification feature, expressed by the structural motivator of a series of units.

\section{Theoretical Framework}

In Russian linguistics, the foundations of the concept of motivology as a science at the intersection of semasiology, onomasiology and synchronic derivation originated in the works of O.I. Blinova (see Blinova, 2012). Motivology interprets motivation as a connection between the form and content of a language unit realized by native speakers, the perceived derivability of its meaning from the meanings of other units, which is based on structural-semantic relationships and is established in contrast to the derivatological approach through the analysis of actualized in speech (in texts or metatexts) motivational relations of units, rather than by studying relations between lexemes at the derivational level (Yurina, \& Zhakupova, 2020).

The motivology interprets the speech actualisation of motivational relations between units as a fact of linguistic/metalinguistic consciousness, as an awareness of the link between form and meaning of a unit due to its lexical and structural correlation with other words of the language.

The concept of motivology includes descriptive motivology, which studies motivation in a specific language and in a specific period (it is implemented in most motivological studies); comparative motivology, which studies the universal and the variation in the mechanism of motivation, motivational reflection in different languages in a specific period; dynamic motivology, which addresses the change of motivation of language units in different time slices. In the framework of motivology there are different research aspects: ontological, methodological, functional, lexicographical, source study and historiographical. (see Blinova, 2012; Khazimullina 2015; Kishina, 2011; Olostiak, 2019; Yurina, \& Zhakupova, 2020). Researchers actively implement a combination of system-structural and psycholinguistic approaches in motivological research, aiming to study through directed psycholinguistic experiments the process of motivation as a lingua-psycho-mental one.
The existing plethora of motivological research confirms the productivity of motivational theory in theoretical, methodological, and applied terms (for a detailed review of works and achievements of motivational theory, see Blinova, 2012).

The current trends demonstrated in the development of motivology are the appeal to linguistic macroobjects aimed at revealing the motivational mechanism and mental structures embodied in language signs: to nominativemotivational models and motivational relations within semantic, pragmatic categories, in thematic, lexical-semantic groups of vocabulary, in groups of neo-lexemes; to the image structure of language; to the system of motivationalassociative fields in different languages and their cognitive structure, etc. (see Yurina, \& Zhakupova, 2020).

In the 21st century there are a number of scientific works devoted to the problems of neology in the Russian language, reflecting the study of new words in different aspects and from different positions: the main current trends and unusual ways of derivation, modern borrowings, the functions of neo-lexemes in various communicative practices, the difficulties of their lexicography, derivational families of neolexemes with homonyms, the implementation of evaluation by neologisms, neological lingvocreativity, etc. (for review see Yuxin, 2016; Kozlovskaya, 2020). Addressing research macro-objects (different paradigmatic subsets of units, neological lexical-semantic categories) is also a current trend in the development of neology. The many neo-nominations with the semantics of enmity that are emerging today and function in Internet communication as a reflection of the needs and linguistic consciousness of native speakers attracts the attention of linguists.

\section{Methodology}

The object of research is actual lexical units (LUs) with enmity semantics, used to designate a subject in media and internet communication in the period of 2000-2020. They implement different types of motivation but are united by the presence of foreign derivational components and the special role of structural motivation in forming the semantics of enmity and motivational word meaning.

We include the selected neo-lexemes in the studied lexical paradigm according to their significative and/or pragmatic components of meaning. 
The approaches used include system-centric and text-centric, semasiological and onomasiological approaches, motivational, functional-semantic and contextual analysis.

Motivation is understood as a lexical-semantic category; a nuclear, systemic, structuralsemantic, independent property of a word, consisting in the relative interdependence in the synchronic and diachronic plans of formal, semantic, functional and meaningful characteristics of LUs in the language system and in speech (see Kishina, 2011; Khazimullina, 2015; Ulrich, 2017; Yurina, \& Zhakupova, 2020). This property of a word reflects the linguistic knowledge, perceptions and needs of native speakers.

The lexical and structural correlation of the units determines the rationality of the form-content relationship. Motivationally related units (motivated word/motiveme; motivational words/ lexical motivators (LM) and structural motivators (SM)) form a motivational paradigm, representing (along with motivational contexts) the lexical unit as an element of linguistic, metalanguage consciousness (Blinova, 2012).

The internal word form (IWF) is seen as a concentration of systemic lexical relations, the morpho-semantic structure of a word that reflects its motivation and "interpretation" of reality. IWF combines motivational form (MF) and motivational meaning (MM). MF are meaningful, motivation-driven component(s) of the material envelope of a LU. MM is the synthetic meaning of the motivational form. In this case, LM expresses a motivational attribute / features (MA) and SM expresses a classification attribute / features (CA) (Blinova, 2012). Analysing the IWF of constituents in a lexical paradigm allows characterising the MA, CA, nominative-motivational patterns typical of a particular subject area. IWF can be living, i.e. realised by contemporary speakers; dead, i.e. not realised by linguocultural community members; metaphorical, i.e. expressing the meaning of similarity; variant, i.e. having different MF and MM; lexicalised, i.e. including MF component(s) not being explained by native speakers.

Motivation can be absolute (correlation with extra-linguistic reality) and relative (lexical, structural correlation with other words of the language as LM, SM); complete (the connection of an LU with LM and SM is realized) or partial (only the connection with either LM or SM is realized); phonetic (the connection with the acoustic image of the denotation is realized), morphological (the connection with other wordsmotivators is realized) and semantic (the connection between form and meaning of an LU is mediated by semantic derivation) (Blinova, 2012).

\section{Results and Discussion}

I. Due to the semantic "contribution" of the component to the semantics of the motiveme, we classify LUs with the phobe component as the studied subset, attributed to the vocabulary of enmity based on the significative component of their meaning. Phobe is a foreignlanguage morpheme (Greek) that contributes the meaning "averse, enmity and fear of that which is named in the first part of the word" (Efremova, 2000). According to the corpus data, one of the most frequent LUs for the period is the noun Ukrainophobe (subgroups "National discord"/"Incitement to hatred"), which refers to the vocabulary of enmity based on denotative signs in the meaning.

Ukrainophobe. MF: UKRAIN/o/PHOBE or UKRAINOPHOBE. LM: Ukraine, Ukrainian,

Ukrainophobia. SM (Ukrainophobe $\leftarrow$ Ukraine / Ukrainian): yudoPHOBE, russoPHOBE; CA: "averse, enmity towards the named first component". MA: "a subject related to Ukraine/Ukrainian" or "a subject associated with Ukrainophobia". MM: "<one $>\square$ who is enmity $<$ towards $>$ Ukraine" / "<one> who is enmity $<$ towards $>\square \leq$ everything Ukrainian $>$ " or "<one who $><$ is a supporter $>\square$ of Ukrainophobia" (in angle brackets there are elements that are not explicit in the MF, IWF, but necessary to form $\mathrm{MM}$ as an expression). According to the Internet communication data, the LU Ukrainophobe correlates with several lexical motivators, which causes the existence of variants of MF and MM. The IWF of these LU is living, non-metaphoric, non-lexicalised, variant (in the order of actualisation frequency: Ukrainophobe $\leftarrow$ Ukraine; $\quad$ Ukrainophobe $\leftarrow \quad$ Ukrainian; Ukrainophobe $\leftarrow$ Ukrainophobia); motivation is complete, relative, morphological. Example of motivational context: People who oppose everything Ukrainian, ... Ukrainian statehood, self-determination of the Ukrainian nation are called "ukrainophobes" ... (Berdnik, 2011). According to the LEEDS corpus, LU forms collocations with the adjectives odious, fierce terry. As a syntactic subject, LU is most often combined with the verbs to persuade, to resent, 


\section{AMAZONDA \\ Investiga}

to destroy. The LU-partners point to the attributes of the denoted subject "irreconcilable", "causing negative emotions", "emotional about something/someone".

We classified the following LUs as enmity vocabulary based on pragmatic components in their meaning.

II. The second group may include the LUs with the common semantic attribute "negative assessment of intellectual abilities" (subgroups "National discord", "Incitement to hatred"; "Fight", "Insult").

This group includes occasional neo-lexemes with the -phrenic component, functioning as an insulting designation of a) a subject representative of a nation (LM is an ethnonym or ethnopholism); b) a subject - a supporter of a political / public figure (LM is a proper name). The SM determines the semantic and motivational characteristics of a LU in a meaningful way. The SM oligoPHRENIC and subsequent new lexemes with this SM cause the formation of the transformed CA "muddleheaded, mentally retarded" (see the similar meaning of the component -phrenic from

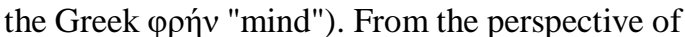
derivation, we can consider these units as blending (telescoping) (Grigorieva, 2019), where one of the lexical units connected with syncopation is the word oligophrenic ("colloquial about a stupid, unintelligent or abnormal, strange person (Kuznetsov, 2000)), setting the morphological pattern, the accent and syllable structure of the new word. Both derivative bases are semantically significant, complementing significative and pragmatic features (compare liberophrenic, trampophrenic). The second component carries an intellectual evaluation value (see the above transformed CA); the first component also contributes to the evaluative component of meaning at the level of individual/common connotations.

For example: a) Ukrophrenic (telescoping: $u \mathrm{kr} /$ ukrainian + oligophrenic): MF: ukr/o/phrenic; MM: <"one who belongs to> Ukrainians / ukrains <and $>$ is dumb" (... Dmitry is not a dumb ukrophrenic person [Etoonda, 2014]); the LU is more often used as an invective appeal; in Internet communication the LU-partners dumb, euphoric, muddleheaded; to demand, to portray, reflecting the attributes of the named subject "emotional", "unintelligent"; b) Stalinophrenic (telescoping: Stalinist + oligophrenic): MF:
Stalin/o/FRENIC; MM: < "one who belongs to Stalin's supporters $>$ and $<>$ is stupid" (Stalinophrenic people of all stripes and other potsriots will be ripped...) (Slovohotov, 2013); the LU, most often, functions as an invective address, as part of name sentences; the recorded repeated partner LU (modern, enthusiastic, rip, drive yourself) reflects the subject attribute "emotional", "inadequate".

In this group we also include a set of occasional negative evaluative identifications of the subject with the morpheme -saur [from Gr. sauros "lizard"]. The subset of LUs described below includes:

1) LU with LM ethnonyms (subgroup "National discord"); e.g.: Americanosaur; MF: AMERICAN/o/SAUR; LM: America, SM: dinoSAUR; CA: "(mentally) retarded, primitive subject clarified by LM"; MA: "a subject connected with America"; MM: "<one $>\square$ who is American <and $>$ thinks primitively $<$ like $>\square$ a lizard". IWF is living, metaphorical (identification with a dinosaur), motivation is complete, relative, semantic-morphological (Tell us about the rights of illegals in America, you are our learned americanosaur!). (Amitel, 2014); Americanosaur is used as an invective reference, in noun sentences; it is rarely combined with adjectives, there are also recorded combinations of the $\mathrm{LU}$ as a syntactic subject with the verbs to seek, to bite, to be furious; LU-partners actualize the attribute of the named subject "aggressive".

2) LUs with LM proper names (subgroups "Fight", "Insult"): a) to characterize: the bearer of this name; e.g.: Trumposaur; MF: TRAMP/o/SAUR; LM: Trump, SM, CA, IWF, motivation - as in No.1; MA: "Trump as a subject with certain characteristics"; MM: "Trump <because he thinks primitively like $\quad$ a $>\square$ lizard (e.g.: Trumposaur carries a troubled time. Donald Trump has won a ... brilliant victory ... and thus condemned the US Republican Party to a ... troubled time ...) (Kozlovskij, 2016); LU-partners - hateful, with ... even less of a brain, to speak out, to rest on one's laurels, to devour, to act, to meet, to humiliate reflect the attributes of the subject "inconsiderate", "predatory", "unpleasant"; b) to characterise the supporters of the name bearer; e.g: Stalinosaur; MF: STALIN/o/SAUR; LM: Stalin; SM, CA, IWF, motivation - as in No. 1, 2a; MA: "associated with Stalin"; MM: "<one> who 
$<$ supports $>\square$ Stalin <and thinks primitively like $>\square$ a lizard" (Lenin and the revolution are bad, but Stalin and the USSR are good. ... liberal malcontents, and wistfully nostalgic Stalinosaurs (Bagrov, 2019)); the recorded LU-partners - to wash over, no brains, stupid, caveman, dumb-headed, rabid, soviet, marasmic, nostalgic, extinct, to run up, to appear, to shout, to forget reflect the attributes of the subject "stupid", "retarded";

3) LUs with LM denoting socio-political currents; e.g.: liberosaur; MF: LIBER/O/SAUR; LM: liberalism or liberal; SM, CA, IWF, motivation as in No.1, 2a, 2b; MA: "relating to liberalism / liberal values"; MM: "<one $>$ who is liberal / $<$ supporter $>\square$ of liberalism < and primitively thinks like $>\square$ a lizard" (And "pan-human beings", including our liberosaurs ... do not consider this a shame) (Yakemenko, 2013); LU is used in imperative sentences, invective references. In terms of derivation, we can also see the neo-lexemes described as products of telescoping, for example: American + dinosaur, Stalinist + dinosaur, liberal + dinosaur, etc. The LU dinosaur is a morphological model; figuratively, a person with outdated notions, beliefs, unwilling to adapt to new realities, retarded (see Ozhegov, \& Shvedova, 1992). Blending is a serial feature. In the described cases the suffix -oid shows a change in the functional sphere, i.e. atypical combinatorics (traditionally the morpheme is used to form terms - names of extinct reptiles); as a result of serial blending, multiple telescoping neolexemes one can assume an emerging tendency to associate -saur with a new meaning ("(mentally) retarded, primitive").

The next example of LUs of this group illustrates the tendency to use an independent word as a derivational component.

LUs formed with the participation of ethnonyms (subgroup "National discord"), proper names, chrononyms, names of socio-political trends (subgroups "Fight", "Rivalry") and the morpheme -down, belong to the enemy vocabulary according to the pragmatic features in their meaning. The realised negative evaluation stems from the meaning, the stylistic characteristic of the down component (down - "a colloquial, disparaging or ironic, about a person with a low level of intelligence") and the individual connotations of the LM. There is also atypical combinatorics (atypical use of LU down to produce composites). SM (DAUN, liberDAUN, MayDAUN, kremleDAUN, trampDAUN) express CA "mentally muddleheaded subject associated with a named LU". For example, liberdown (LIBER/DOWN): LM: liberal, MA: "a subject related to liberals"; MM: "one $<$ who is $>\square$ pro-liberal <and mentally handicapped, like a person with $>\square$ Down syndrome"; IWF: living, metaphorical; motivation: total, relative, semanticmorphological (Typical liberdown. In any measure ... looks for a catch and oppression. ...P.S. This does not apply to adequate liberals) (Crim, 2020); LU-partners are typical, regular, very heavy, stupid; look for a catch, invent, blow it out, pretend - reflect attributes of the subject "narrow-minded", "gullible", "negatively disposed".

There is a similar phenomenon illustrated by LUs formed with the component hater (English noun formed from the verb to hate which means "malcontent, sworn enemy, anti-fan") in combination with ethnonyms (subgroup "National discord"/"Incitement to hatred") or proper names, designations of socio-political trends (subgroup "Fight"). An example is Liberhater. MF: LIBER/HATER. LM: liberal, liber; SM: TrampHATER, PUtinHATER, StalinHATER, UkroHATER, KremlinHATER; CA: "one who hates the one named by the first component"; MA: "a subject associated with liberals"; MM: "one <who> hates liberals". IWF is living, non-metaphorical; motivation is complete, relative, morphological. The LU with the component -hater belongs to the first described group by its significative features (see I).

III. The next LUs also belong to the enemy vocabulary based on the pragmatic components in their meaning. The common semantic attribute "negative characteristic of the subject's mental properties" brings the following LUs into a common group.

This group of subject denotations includes, for example, neo-lexemes formed with the help of the suffix -oid, which have a negative evaluative semantics): a) LUs with proper names (e.g: Yeltsenoid, Stalinoid, Clintonoid, Trumponoid, Putinoid, Navalnoid; subgroup "Fight", "Incitement to hatred"); b) evaluative LUs with LM ethnonyms (for example, Americanoid, Europeanoid; subgroup "National discord" / "Incitement to hatred"); c) the LU formed from precedent names (chrononyms, toponyms), names of socio-political currents (e.g. oranoid, 


\section{AMAZONIA
Drvestiga}

kremloid); "Fight" / "Incitement to hatred" subgroup; d) the LU with the occupational name (deputoid), socio-political currents (liberoid); subgroup "Fight" / "Incitement to hatred" . The evaluative value of these LUs depends on the individual connotations associated with the LM and the connotations associated with the SM, which condition the formation of the transformed CA.

The component -oid originates from the Greek

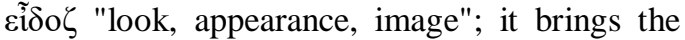
meaning "similar, like that which is called by the motivating noun"; see the dictionary entry on this derivational unit (Efremova, 2000). The data of the involved corpora, Google N-gramm-Viewer servers, Google Trends, Yandex.Statistics, Yandex.Blogs platform show the implementation of neo-lexemes with -oid exclusively negative evaluation and the functional limitations of pragmatic nature (the LU is used only by the opponents of the person called LM). These facts allow assuming a connotative reinterpretation of CA influenced by the analogy reflected by SM (e.g. schizOID, hysterOID): CA - "similar to LM, but handicapped / abnormal / inadequate / with psychiatric pathology". This means that the original attribute of similarity was supplemented by the attribute of inadequacy, abnormality and negative evaluation. The described motivemes refer to the expression of a pejorative attitude.

For example:

Americanoid. This refers to the formation of a new lexical-semantic variant (LSV), along with the LSV denoting the indigenous inhabitants of the Americas, the Indians (an anthropological term). The new LSV denotes modern Americans and implements a negative evaluation. According to V.N. Trishin's dictionary, a synonym for Americanoid is the noun hamburger-eater (Trishin, 2013). MF of LU Americanoid: AMERICAN/OID. LM: American, an American. SM: schizOID, liberOID, trampOnOID; CA: "abnormal, inadequate, similar to that named by LM". MA: "a subject of relevance to the people of America". MM: "someone <abnormal, inadequate $>$, $<$ like $>\square$ American, similar $<$ to $>\square$ everything American". IWF is living, metaphorical (negative interpretation of similarity - such as..., but inadequate); motivation is complete, relative, semantic-morphological. Example of motivational context: Typical Americanoid. Not an American, but a product of the American approach to work (Batumi, 2014). We detected the following LU-partners: typical, one hundred percent, ordinary, plastic-celluloid, monstrous, drunken, loose, pale, vulgar, to turn, to transform, to contrive (expressed attributes of the subject are "product of the system", "harmful", "unhealthy way of life").

Orangeoid. MF: ORANGE/OID. LM: orange (associated with the Orange Revolution). SM: hominoid, schizoid, liberoid, americanoid (CA: see above). The negative assessment is due to the reinterpreted meaning of the component -oid and the connotations of LM. The LU is used today with 2 meanings: 1) to denote supporters of $\mathrm{V}$. Yushchenko, activists of the series of opposition actions on 22.11.2004-23.01.2005 in Ukraine, which became known as the "Orange Revolution"; 2) to denote participants/ supporters of the rally on Bolotnaya Square in Moscow in 2012. (compared to the Orange Revolution). MA: "a subject associated with the Orange Revolution". MM: "<abnormal, inadequate>, as $<$ a participant in the $>$ Orange $<$ Revolution $>$ ". IWF is living, metaphorical (negative interpretation of similarity, transposition: orange revolution $\rightarrow$ (orange) participant / revolution supporter); motivation is complete, relative, semantic-morphological. Example of motivational context: "The Mean Time" at the time of the Orange ... turmoil ... called itself the "third force". ... We declared ... our ... deepest hatred for the Orangeoids. ... gathered on Poklonnaya Gora, where we fought back ... against the "orange plague" ... (Arhiseva, 2015). The Internet communications show definitions of explicit, convincing, accomplished, main, odious, conniving, typical, unprincipled, lacking ideology; the LU combines with words as a syntactic subject and verbal units to talk, to deny, to tell, to muss, to puff up, reflecting the subject attributes "aggressive", "engaged", "dishonest". Liberoid (LU is introduced by S.E. Kurginyan). MF: LIBER/OID. LM: liberal (see also liber is contemptuous of a liberal). SM: OrangeOID, ClintonOID, etc. (CA is as in other LU with oid). MA: "a subject related to a liberal". MM: "<such $>$ as < abnormal $>$ liberal". IWF is living, metaphorical; motivation is complete, relative, semantic-morphological Example of motivational context: A liberoid is a person who ... says he is a liberal ... but acts ... back to liberal principles ... (Timonin, 2017). We found collocates indicating the attributes of the subject "known for negative qualities", "dangerous": egregious, stubborn, destroy, act, to shout, etc. (LEEDS, 2005-2017).

From the point of view of derivation, the described neo-lexemes can also be considered as products of telescoping (Stalinist / Putinist / 
Yeltsinist, etc. + schizoid; American + schizoid, liberal/liber + schizoid; orange + schizoid; schizoid acts as a morphological pattern). Blending is a serial feature. The suffix -oid is typical of special vocabulary and used in the cases analysed to form words with other functional, stylistic characteristics; there is a tendency to associate the suffix with a changed meaning ("similar, but not normal"). The following meta-language comment of the blogger is noteworthy: "I will use the suffix "-oid" to refer to those people who take any unflattering statement about their idol as a personal insult, ... Real communists can be called Leninoids" (Zelichenko, 2013).

This group of subject designations also includes neo-lexemes formed with the Russian-language component -oholik. The English suffix -oholic is involved in the formation of nouns denoting a dependent subject pathologically from something (The American Heritage Dictionary, 2011). The Russian equivalent has a similar meaning. The subject designations formed with its participation (e.g. Ukroholik, Demokratoholik, Trampoholik) implement a negative evaluation (subgroup "National discord" / "Incitement to hatred" / "Fight"). Influenced by the analogy with SM, the individual connotations associated with LM form the CA "fixated, turned on something". We will consider the occasionalism of a trampoholic. MF: TRUMP/OHOLIC. LM: Trump. SM: alkOHOLIC, shopOHOLIC. MA: "a subject related to Trump"; MM: "one $<$ who $>\square<$ is fixated on $>\square$ Trump, pathologically devoted to him". IWF is living; motivation is complete, relative, semantic-morphological. For example: What should we do now with our trampoholics and tramp-fans? (Mk.ru, 2017); we revealed LUpartners known, typical, weak-minded, rabid (reflected attributes "unintelligent", "inadequate"). The named neo-lexemes can also be interpreted as products of telescoping (e.g. trampist + alcoholic, etc.).

Group III also includes LUs formed with the morpheme -path (from the Greek $\pi \alpha \dot{\theta} \theta$ o $\zeta$ meaning "everything that one undergoes (experiences), feeling, suffering" (Efremova, 2000). These LUs denote a subject associated with a socio-political or ideological current. The negative evaluation they realise (see e.g. liberopath, putinopath) is determined by analogy with the SM and the connotations of the LM. Liberopath (subgroup "Fight"). MF: LIBER/o/PATH. LM: liberal. SM: socioPATH, psychoPATH (transformed CA: "arriving in a painful state of attachment to someone, something, who/what is named by the
LM"). MA: "a subject related to liberalism, liberal values"; MM: "one $<$ who $>$ is painfully $<$ attached to $>$ liberal < principles $>$ ". IWF is living; motivation is complete, relative, semantic-morphological. An example of a motivational context: ... I have a ... term: "liberopath", meaning a person who pathologically, ... morbidly holds on to liberal values (Lopatnikov, 2009). Internet communication contains adjectives in the function of the definition revived, marketable, and the participle assertive; the LU rarely functions as a syntactic subject. These units can also be interpreted as the result of telescoping (e.g.: liberal + psychopath).

A similar meaning is realised by subject designations formed with the morpheme - $\underline{\text { man }}$ (from the Greek $\mu \alpha v i$ í "frenzy, madness; delight"; - "the final part of compound nouns that introduces the meaning: passionate lover of that which is named in the first part of the word" (Efremova, 2000). A subset of these LUs is constituted by subgroups: a) with LM - a proper name, denoting a socio-political trend (Navalnoman, Putinoman, Stalinoman, Trumpoman; subgroup "Fight"); b) with LM ethnonym / ethnopholism, name of a country (for example: Ukrainoman, Americanoman; subgroup "National discord" / "Incitement to hatred").

For example: Stalinoman. MF: STALIN/o/MAN. LM: Stalin. SM: kleptoMan, necroMan, drugMan, gamblingMan; CA: "pathological, passionate adherent of the one named by LM"). MA: "a subject related to Stalin". MM: "the one $<$ who $>\square$ is a pathological, passionate $-<$ adherent $>$ of Stalin". IWF is living; motivation is complete, relative, semanticmorphological. For example: ... those who glorify Stalin today, they are surely worse than the Nazis. ... Without the Kremlin's resource, the Stalinmans would remain a marginalised group of urban madmen (Solvaig, 2015). The Internet communication captured LUs: furious, raging, stubborn, obstinate, great, sick, aggressive; to listen to, to drag, to interpret, to perceive, to exult, to shout, reflecting a negative attitude towards the subject, its attributes "suggestible", "emotional", "abnormal", "insistent". We can also consider these units as being formed by telescoping (e.g. Stalinist + drugman).

IV. The following LUTs attributed to the enmity vocabulary based on the pragmatic components in their meaning can be grouped into a subgroup by the 


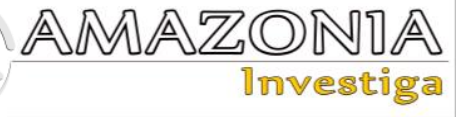

common semantic attribute "negative moral characteristic".

This group includes, for example, LUs associated with socio-political movements, ideas, subject designations ending in the component -erast/rast, associated with the designation homosexual $\left(\mathrm{LSV}_{1}\right)$ and its derivative vulgar invective name of males (LSV 2 ; [Wiktionary, 2019]) (subgroup "Fight" / "Incitement to hatred" / "Insult"). The most frequent one is the LU liberast. MF: LIB/ERAST. LM: liberal. SM: fedERAST, sepaRAST, tolERAST, deputAST; transformed

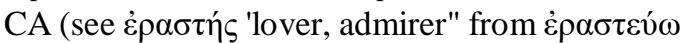
"to love"): "an abhorrent, unworthy, perverse supporter of something"; MA LIB/ERAST: "a subject related to a liberal". MM: "<the kind of $>\square$ liberal <who is $>\square$ disgusting, perverse". IWF is living, metaphorical; motivation is complete, relative, semantic-morphological Example of a motivational context: In Russian educated ... circles ... the dominant ... has become the type of Westernised liberal ... popularly called "liberast" (National corpus of the Russian language, 2010-2021). The most frequent collocations include: typical, venal, Russian, crazy, interested, cursed (LEED, 2006-2010), partner verbs recorded in Internet communication are to rant, to get rid of, to hate, to compose, to trample. LU-partners reflect negative attitudes towards the denoted subject, their attributes of "dishonourable", "emotional", "active", "inadequate". We can also consider LUs belonging to this subset to be formed as a result of telescoping, its serial nature can be traced; the seriality of the analogy reflected by the new telescoping units may indicate the association of the component $-(e)$ rast with a modified meaning "perverted, disgusting".

\section{Conclusions}

Structural motivation is a significant phenomenon in shaping the semantics of units and motivational relations in the lexico-semantic system of language. The development of contemporary Russian-language enmity vocabulary is characterised by the following vectors: integration, intensification, internationalisation and intellectualisation. These trends define modern nominal derivation and contribute to new realisations of the possibilities in the language system. Intensification correlates with the transgressiveness of contemporary media, i.e. their focus on maximising the purposeful "power of the text" and the "communicative will" of the addressee in a particular chronotopic segment of communicative space. Our material reflects this in expressivisation at the lexical level, including an attitude of emotional construction of social reality (Rebrina, \& Shamne, 2020). Integration manifests in the transition of special derivational means into the common language, softening of stylistic boundaries and orientation towards the pragmatic axis of the norm; internationalisation in the active use of foreign affixes; intellectualisation - in the frequency of metaphorisation, appeal to associations and analogies, the rebus effect. The topical trends are the formation of LUs through the use of derivation instead of syntagmas, activation of non-usual ways of derivation (blending) and nomination by analogy, the increasing role of onyms; the greatest activity of derivational components expressing the meaning of enmity and negative evaluation. The described subject designations belong to the vocabulary of enmity according to the significative or pragmatic components of their meanings, realising a negative assessment of the subject according to his intellectual, psychological and moral characteristics. The emphasis in IWF on the negative properties of the subject through the actualisation of lexical/structural motivation; the opposition of subjects on the axis "adversary supporter"; the active realisation of subjective modality and the contextual actualisation of the paradigmatic value of units; the possibility of individual motivation of occasional formations determines the discursive disclosure of motivational relations and the internal form of new lexical units.

\section{Acknowledgments}

The study is supported by Russian Science Foundation (project No. 20-68-46003 "The Semantics of Unity and Animosity in Russian Lexis and Phraseology: Language System and Discourse").

\section{Bibliographic references}

American Heritage Publishing Company (2011). The American Heritage Dictionary of the English Language. 4. Edition. Boston: Houghton Mifflin Company. ISBN 0547041012. 2084 p.

Amitel (2014) Russia will not exchange schoolchildren with the United States because of a homosexual couple adopting a Russian child. Barnaul and Altai Territory news. Recovered from https://www.amic.ru/news/283648/.

Anscombre, J.-C. (2019). Idiomaticity, lexicon and lexical schematas. Cahiers de Lexicologie, $\quad 1(11), 119-147$. URL: 
https://classiques-

garnier.com/export/pdf/cahiers-de-

lexicologie-2019-1-n-114-les-phrases-

prefabriquees-sens-fonctions-usages-

figement-lexique-et-matrices-lexicales.html.

Arhiseva (2015). Livejournal. Orthodox, get a grenade from RNL Stepanov. Recovered from

https://arhiseva.livejournal.com/95745.html.

Bagrov, D. (2019). On the origins of the Kremlin's love and hatred of Stalin. Levoradikal. Recovered from https://levoradik_al.ru/archives/17150.

Balestero, M. D., Clempi, C. B., \& Da Costa, D. S. (2020). Processes of neologism formation on instagram. Revista da Anpoll, 1(51), 83-95.

Batumi, G. (2014). Mikhail Slobodin, who loved to talk about how to become rich and successful, fled Russia with money?, Livejournal. Puerrtto. Recovered from https://puerrtto.livejournal.com/640686.html

Berdnik, M. (2011). Varjag_2007, They want to equate Ukrainophobia with anti-Semitism. Livejournal. Recovered from https://varjag2007.livejournal.com/2495481.html?page $=2$.

Blinova, O. I. (2012). Key terms of motivology: the test of the time (1971-2011). Tomsk State Pedagogical University Bulletin, 10(125), 136-140.

Cano, D. P. V. (2020). Word formation by external motivation in Spanish and French. XLinguae, 13 (1), 225-236. Recovered from http://xlinguae.eu/files/XLinguae1_2020_17. pdf

Chishman, R., dos Santos, A. N., \& Martins P. (2020). The lexical neology phenomenon in the 2018 elections. Water Line, 33(1), $129-149$.

Crim (2020). Internet community Pikabu. I really hope this is just trolling. Pikabu Newsletter. Recovered from https://pikabu.ru/story/ochen_nadeyus_chto_ yeto_prosto_trolling_7326945?cid=1651702 29.

Detry, F. (2017). Idioms in French as a foreign language: memorization strategies and structural motivation. Anales de filologia francesa, 25, 331-348.

Dobrovol'skij, D., \& Piirainen, E. (2018). Conventional Figurative Language Theory and idiom motivation. Yearbook of Phraseology, 9 (1), 5-30.

Efremova, T. F. (2000). New explanatory and derivational dictionary of the Russian language. Moscow: Drofa.

Etoonda (2014). The massacre will be not only in Donbass, Recovered from https://etoonda.livejournal.com/594215.html
Galitsyna, E.G. (2018). Plant names of FinnoUgric Languages Motivated by Plant Parts Form and Their Equivalents in the English language: Comparative Analysis. Nauchnyi dialog, 5, 49-59.

Gombocz, E. (2013). Contrastive word form analysis German-Hungarian. Word families from a didactic and lexicographical aspect, 44. Mannheim: Institute for the German Language.

Grigorieva, P.V. (2019). Blending as a type of unusual derivation: to clarify the concept. The World of Science, Culture, Education, 3 (76), 488-490.

Khazimullina, E. E. (2015). General linguistic theory of motivation: to the statement of the problem. Questions of Cognitive Linguistics, 2(043), 144-155.

Kishina, E.V. (2011). The nature of motivational and metalanguage connections in political texts. Actual problems of modern word formation: collection of scientific articles. Kemerovo. Kemerovo State University, 4, 413-418. Recovered from https://www.elibrary.ru/item.asp?id=224210 34.

Kozlovskaya, N.V. (ed.) (2020). New words and dictionaries of new words: Collection of scientific articles. St. Petersburg: Institute for Linguistic Research RAS.

Kozlovskij, V. (2016). Kstati. Trumposaurus carries the Time of Troubles. Newspaper of Russian American News and Views. Recovered from https://kstati.net/trampozavr-neset-smutnoevremya/.

Kuznetsov, S. A. (Ch. Ed). (2000). Big Dictionary of Russian Language. Saint Petersburg: Norint. Recovered from https://gufo.me/dict/kuznetsov.

LEEDS. (2005-2017) Russian corpora of the University of Leeds. Electronic resource. Recovered from http://corpus.leeds.ac.uk/ruscorpora.html.

Lopatnikov, S. (2009). A word about words. Livejournal. Recovered from https://sllopatnikov.livejournal.com/169470.html.

Mk.ru (2017). Newspaper "Moscow's comsomolets". Letters to Heads of State. Recovered from https://www.mk.ru/culture/2017/03/17/pism a-glavam-gosudarstv.html.

Morozkina, T., Rusinakova, J., \& Ivanova, L. (2020) Phonosemantic interpretation of lexical units in the context of Russian and Slovak linguocultures. Amazonia Investiga, 9 (29), 496-506. https://amazoniainvestiga.info/index.php/am azonia/article/view/1414 


\section{AMAZOND㲏 \\ 1nvestiga}

National corpus of the Russian language (2010-2021). official website. Electronic resource. Recovered from https://ruscorpora.ru.

Olostiak, M. (2019). Theory of lexical motivation in Slovak lexicology. Skase journal of theoretical linguistics, 16, 3, 136- 155.

Ozhegov, S.I., \& Shvedova, N.Yu. (1992). Explanatory dictionary of the Russian language, Moscow: Az. Electronic resource. Recovered from https://ozhegov.slovaronline.com/.

Rebrina, L. N. (2020). Semantic and Motivational Characteristics of Neolexemes of Enmity: Discursive Disclosure of Inner Form of the Word. Nauchnyi dialog, 8, 141-155.

Rebrina, L.N., \& Shamne, N.L. (2020). Systemic-Communicative Dimensions of Modern Protest (based on German-Language Online Petitions). Nauchnyi dialog, 3, 151-167.

Slovohotov, A. (2013). Photo of the day, 01.07.2013, comment of Sokolov D. Livejournal. Recovered from https://slovo13.livejournal.com/881550.html

Solvaig (2015). Stalinomania - the dry residue of Crimeanism. Livejourna. Recovered from https://solvaigsamara.livejournal.com/94797 4.html.

Timonin, D. (2017). DAS_FOLAND, Where I came from, I don't know. Livejournal. Recovered from https://dasfoland.livejournal.com/369788.html

Trishin, V.N. (2013). Electronic dictionary of synonyms of the Russian language of the ASIS system. NVI. Recovered from

http://rus-yaz.niv.ru/doc/synonymstrishin/index.htm.

Ulrich, W. (2017). Morphological awareness How it helps us understand unfamiliar words. The Language Service, 6, 264-276.

Ulrich, W. (2020). Prayed and exhausted! Between Occasionalisms and Neologisms. Zeitschrift für germanistische Linguistik, 48 (1), 167-186.

Umbreit, B. (2010). Does love come from to love or to love from love? Why lexical motivation has to be regarded as bidirectional. Cognitive perspectives on word formation, 221, 301-333.

Wiktionary (2019). Multilingual, web-based project. Electronic resource. Recovered from https://ru.wiktionary.org/wiki/\%D0\%BF\%D 0\%B5\%D0\%B4\%D0\%B5\%D1\%80\%D0\%B $0 \% \mathrm{D} 1 \% 81 \% \mathrm{D} 1 \% 82$.

Yakemenko, B. (2013). Vultures, comment of Credward. Livejournal. Recovered https://borisyakemenko.livejournal.com/315507.html?th read=14917491\#t 14917491 .

Yurina, E. A. \& Zhakupova, A. D. (2020). The Development of Olga Blinova's Ideas in the Linguistic Conceptions of the Figurative System of the Language and Contrastive Motivology. Filologiya-tomsk State University Journal of Philology, 68, 170-193

Yuxin, B. (2016). Main achievements and actual problems of neology. Bulletin of Kalmytsk university, 2(30), 78-85.

Zelichenko A.I. (2013). Yeltsinoides, putinoides, navalnoides ... (political and psychological study). Livejournal. Recovered from https://russkiysvet.livejournal.com/156651.h tml 